\title{
WAITING FOR INTEGRATIVE TAXONOMY: MORPHOSPECIES AS AN OPERATIONAL PROXY FOR THE RADIATIVE AND RETICULATE GENUS OPHRYS L. (ORCHIDACEAE)?
}

\author{
ERROL VÉLA ${ }^{1, *}$, KHELLAF REBBAS², ROLAND MARTIN ${ }^{3}$, \\ GERAUD DE PREMOREL ${ }^{1}$, and JEAN-MARC TISON ${ }^{4}$

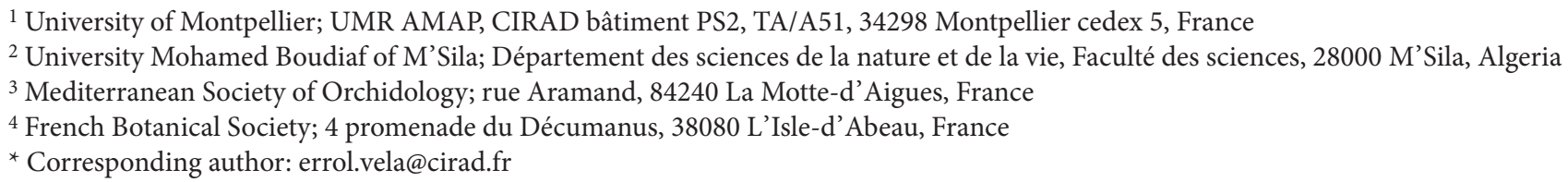

\section{ABSTRACT}

Recently published botanical floras provided an opportunity to develop operational systems for identifying in the field in France of species of the difficult genus Ophrys. Its specific and infra-specific taxonomy is extremely complex because of conflicting points of view and/or insufficient knowledge about specific biological features. In order to produce an identification key based on observable morphological criteria we developed a pragmatic taxonomy suitable for non-expert botanists, which includes "morphospecies" that are unambiguously identifiable based on a number of unique or a combination of diagnostic criteria and "subspecies" that are sets of populations sharing the same geographical and ecological adaptations but not distinctly differing morphologically. The taxonomic scheme reviewed here for the section Pseudophrys is well correlated with the floral chemical signatures of all the French taxa. This intermediate position, between splitters (mainly orchidologists) and lumpers (mainly geneticists), will hopefully enable us to revise the taxonomy of this genus at the EuroMediterranean level.

Keywords: morphospecies, Ophrys, taxonomy

\section{Introduction}

Recent publication of two French floras (Tison and De Foucault 2014; Tison et al. 2014) provided an opportunity to work on French species of the taxonomically difficult genus Ophrys L. (Orchidaceae). As for all classical floras, the main objective of these floras was to develop an operational system for identifying plant species in the field, including difficult radiative and/or reticulate genera like Hieracium L. (Krak et al. 2013), Rosa L. (Ritz et al. 2005) or Ophrys (Breitkopf et al. 2015). The radiative genera are characterised by a long-time isolated clade and then a very quick, intense and recent diversification phase. The reticulate genera are characterised by non-linear diversification phases due to crossing between clades. Both are making the taxonomic assessments more difficult.

Specific and infra-specific taxonomy within the genus Ophrys is extremely complex because of conflicting points of view (splitters vs. lumpers, Table 1) and/or poor knowledge of specific features (pollination, floral chemistry, karyology, phylogeny...). For example, the specific pollinators of 80 of the 250 species are unknown (Delforge 2005), chemotaxonomy seems to be promising (Mant et al. 2005; Véla et al. 2007) but only beginning to be used for delimiting species (cf. Joffard et al. 2014), karyology and phylogenetics are still incomplete and were rarely used to identify species (Soliva et al. 2001; Devey et al. 2008; García-Barriuso 2010) until LFY genes were used (cf. Schlüter et al. 2007a, 2011). It explains why it is still difficult to develop a truly integrative taxonomy, except in a few cases at a regional level and only by considering several but not all aspect of biology (Véla 2007, 2008a; Schlüter et al. 2007b, 2009; Xu et al. 2011).

For field botanists, classical French floras (e.g. Fournier 1947) appear to be obsolete with only 2 taxa in the section Pseudophrys Godfery: O. fusca Link and O. lutea Cav. Currently, a lot of experienced and non-expert botanists have great difficulty identifying orchids despite the abundance of illustrated books on the orchid flora in France (Souche 2004; Bournérias and Prat 2005; Dusak et al. 2009; Delforge 2012), which generally are contradictory with from 6 to 14 Pseudophrys taxa.

Because of this confusion, we decided to produce an identification key based on observable morphological criteria, which is pragmatic and can be used by non-expert botanists. Of course, this provisional taxonomy, although useful, will eventually be superseded by the development of a truly integrative taxonomy (Pires and Marinoni 2010). But pending the outcome of DNA barcoding we need a taxonomy based on morphology (Dunn 2003), especially for Ophrys orchids.

\section{Methodology and Taxonomical Choices}

As herbaria are generally not very useful for studying the flower morphology of the genus Ophrys, we studied populations of living plants in the field. The method used was as follows: 1) In a given country, several popula- 
Table 1 Number of taxa in the genus Ophrys according to authors that can be classified to varying degrees as splitters or lumpers.

\begin{tabular}{|l|c|c|c|c|}
\hline $\begin{array}{c}\text { Number of units } \\
\text { according to maximum } \\
\text { taxonomic level } \\
\text { considered }\end{array}$ & $\begin{array}{c}\text { Delforge } \\
\mathbf{2 0 0 5}\end{array}$ & $\begin{array}{c}\text { Baumann } \\
\text { et al. } \\
\mathbf{2 0 0 6}\end{array}$ & $\begin{array}{c}\text { Pedersen and } \\
\text { Faurholdt 2007; } \\
\text { Faurholdt and } \\
\text { Pedersen 2009 }\end{array}$ & $\begin{array}{c}\text { Devey } \\
\text { et al. } \\
\mathbf{2 0 0 8}\end{array}$ \\
\hline Species & 250 & 65 & 25 & 80 \\
\hline Subspecies & - & 175 & - \\
\hline
\end{tabular}

tions of each species were studied; 2) At each locality, the whole population was surveyed; 3) The variability, based on at least 10 and if possible 30 specimens, was recorded, which also included extreme values; 4 ) We worked in the field and took calibrated photographs in order to record and eventually improve the measurements. 5) For each flower of Pseudophrys, we usually measured: length and width of sepals, length and width of petals, length and width of labellum and width of yellow border, if present (cf. Barriau et al. 2011).

We then classified the specimens studied using the following definitions:

- "morphospecies" are phenotypical entities that can be unambiguously identified based on a number of unique or a combination of diagnostic criteria;

- "subspecies" is a set of populations with the same geographical and ecological adaptations (e.g. specific pollinator, flowering time, etc.) within a morphospecies, which can often be discriminated in terms its quantitative range of variation, but not by an unambiguous morphological criterion;

- unclassified variation includes both intraspecific variability and (at least provisional) taxonomical synonyms.

\section{Cases Studied}

We delimited species and produced an identification key for French and Algerian-Tunisian Ophrys, with particular emphasis on the section Pseudophrys. In France, including Corsica, (Tison and de Foucault 2014) we identified 6 morphospecies of Pseudophrys and considered other specific names to be undistinguished infraspecific variations and/or taxonomic synonyms (at least provisionally). In Algeria (Rebbas and Véla 2013) we identified 12 morphospecies, without considering subspecies (at least at this stage). In Tunisia (Martin et al. 2015) we identified a total of 14 elementary taxa consisting of 12 morphospecies and 2 subspecies.

For the 4 main taxa in continental Mediterranean France (Tison et al. 2014): O. funerea Viv., O. fusca, O. lutea and O. marmorata G. and W. Foelsche, we provided an a posteriori calibration of the morphometric results (Barriau et al. 2011). Box-plot graphs or principal component analyses enabled us to distinguish between discriminant vs. diagnostic criteria: a lot of partially overlapping averages and variances of statistical values can be used to statistically discriminate between taxa but are not diagnostic for their identification and therefore not useful in keys, while in some cases a single criterion or combination of criteria is sufficient to distinguish between taxa, which we call "morphospecies" (Fig. 1):

- a wide yellow border is diagnostic for O. lutea vs. the other three species;

- the length / width ratio of the lip is a discriminant criterion for $O$. lutea and $O$. fusca but not a diagnostic one;

- the relative length of the petals is a discriminant criterion for O. funerea and diagnostic if combined with the shape and colour of the labellum;

- the combined criterion "yellow border + labellum length » is diagnostic for O. marmorata vs. O. fusca.

A comparison of our results with species delimitations based on the floral chemical signature of the main taxa in Mediterranean France and Corsica (Joffard et al. 2014) surprisingly revealed almost the same taxonomic scheme as that deduced from our morphometric study:

- For O. fusca (sensu lato) vs. O. marmorata (sensu lato), the chemical signature is diagnostic, confirming our morphospecies delimitations.

- Within O. marmorata sensu lato (incuding O. bilunulata Risso, O. peraiolae G. Foelche et al. and O. delforgei $\mathrm{J}$ and $\mathrm{P}$ Devillers $\mathrm{T}$ ), the discriminant but not diagnostic chemical signatures suggest possible subspecies, as expected for continental populations (Véla et al. 2007; Fig. 2).

- For O. lutea vs. O. corsica G. and W. Foelsche, the chemical signature is discriminant but not diagnostic, suggesting a subspecies level, not yet formalized in the current floras.

Northwestern Africa (particularly Algeria and Tunisia) is a regional hotspot for the section Pseudophrys. The classical flora (e.g. Maire 1960) already includes 6 species or 9 taxonomic units when infraspecific ranks are considered, plus 3 poorly known taxonomic units, considered to be hybrids by the author. The modern revision of Faurholdt and Pedersen (2009), who are considered to be lumpers, recognize 4 elementary taxa at the species level and 9 if subspecies are included. According to our methodology, there are 14 morphospecies and 19 taxonomic units including subspecies in both Algeria and Tunisia. Five of the six morphospecies in France are also present in north western Africa, but are different sub-species. 


\section{Box plots (bord)}

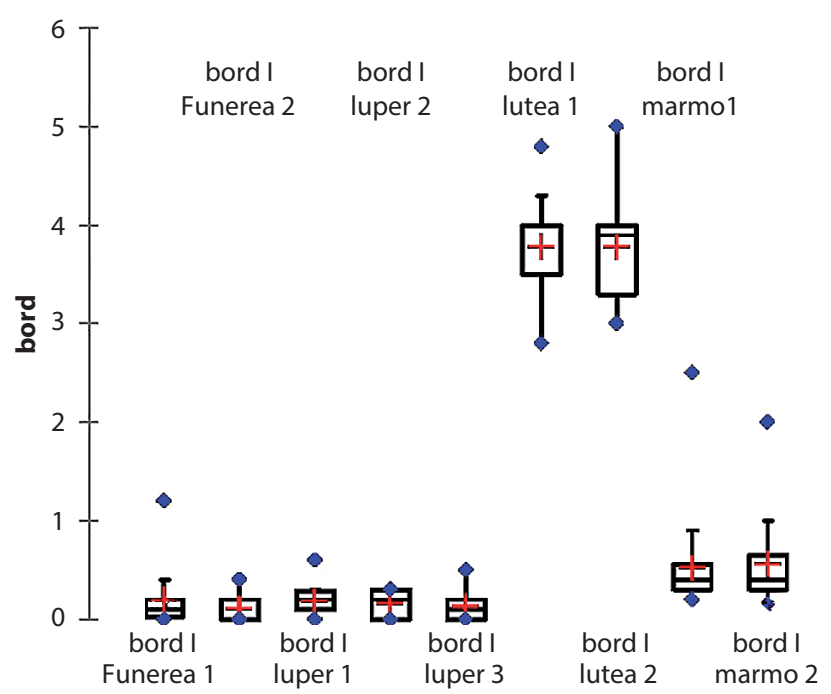

Box plots (L/1-lab)

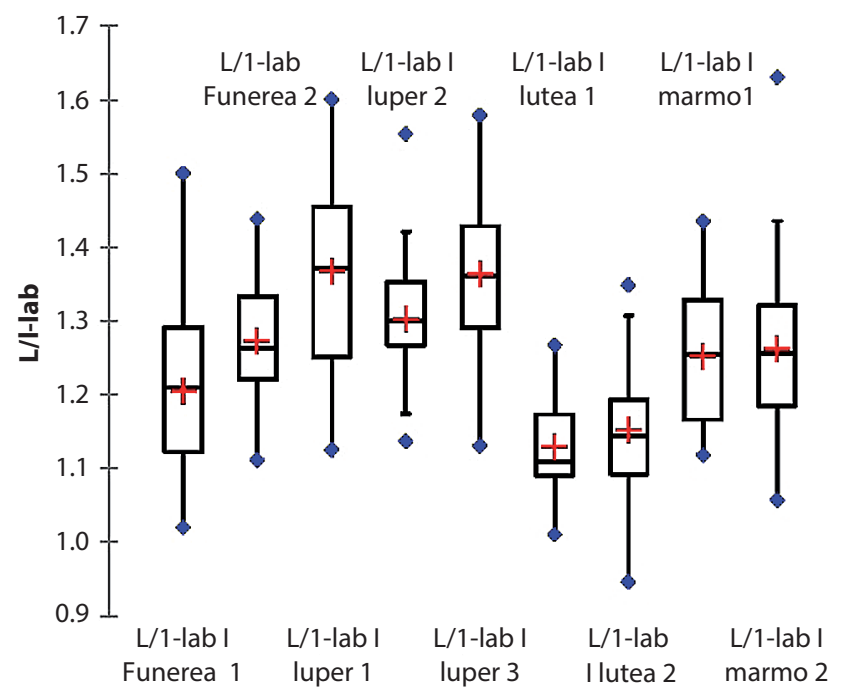

\section{Box plots (Lpet/Llab)}

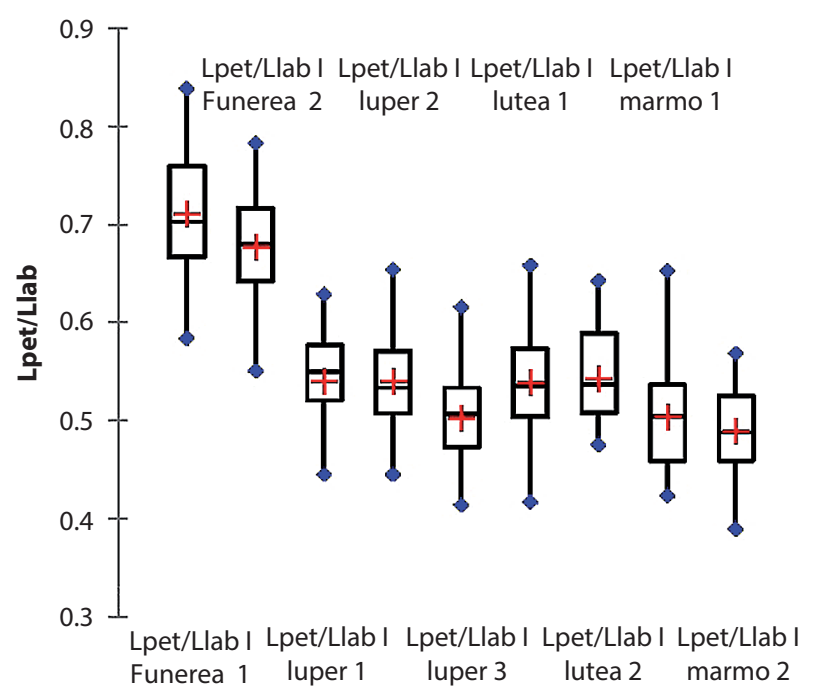

Fig. 1 Box plots of the comparative morphometrics of the labellum of the four main continental French Pseudophrys taxa. Two populations by taxon, respectively $O$. funerea (funerea), O. fusca p.p. $=0$. lupercalis (luper), O. lutea s.s. (lutea), O. marmorata s.s. (marmo). Variables presented here are: width of the yellow margin (bord), length to width ratio of the labellum (L/l-lab), petalum length to labellum length ratio (Lpet/Llab). According to Barriau et al. 2011 (+ unpublished data).

\section{Taxonomic Debate}

The evolutionary biology of genus Ophrys is so complex that several interpretations of its taxonomy are possible (Bateman et al. 2010) depending on 1) which criterion is given priority (morphology, pollination biology, genetics ...), and 2) where the limit between species is placed (splitter vs lumper), i.e. the analytical level and accuracy of our knowledge. Over the last few decades advances were made thanks to studies on pollination biology, which resulted in ethological species delimitations based on species-specific interactions between Ophrys and pollinators (Paulus and Gack 1983, 1990; Paulus
2006). This liberal, pollinator-centred and ethological taxonomy, however, was recently criticised and still remains controversial (cf. Bateman et al. 2011; Vereecken et al. 2011).

The point of view presented here is clearly intermediate between those of the most extreme splitters and lumpers, respectively Delforge (2005) and Devey et al. (2008). From a methodological point of view, our taxonomic delimitations are similar to those of Sundermann, which were formally approved by Pedersen and Faurholdt (Pedersen and Faurholdt 2007; Faurholdt and Pedersen 2009), but with a tendency to split more than lump (cf. Véla 2008b). Simplifying, our subspecies rank corresponds to their variety rank, our species to their subspecies and their species to our non-formal rank of aggregate. Their hybrid complexes, which they treated as species, were carefully studied, and we limited the hybrid appellation to the recently hybridogenic populations that are still morphologically unstable. Using this slightly modified threshold, we provide a more operational proxy, acceptable by both moderate orchidologists and rational botanists. Our analytical level is quite similar to that of Baumann et al. (2006) but gave different results, mainly because they did not have an objective methodology. Depending on the opinion of taxonomists, i.e. if they are more of a splitter or lumper than us, it is possible to use the same framework but change the cursor's position.

\section{Conclusion}

This methodological framework can be used as the starting point of a debate and offers an alternative to the subjective and empirical approaches traditionally developed by orchidologists. As a practical test, the analytical keys for identification can be evaluated by users and improvements incorporated. 
Projection of the cases on the factor-plane (1×2)

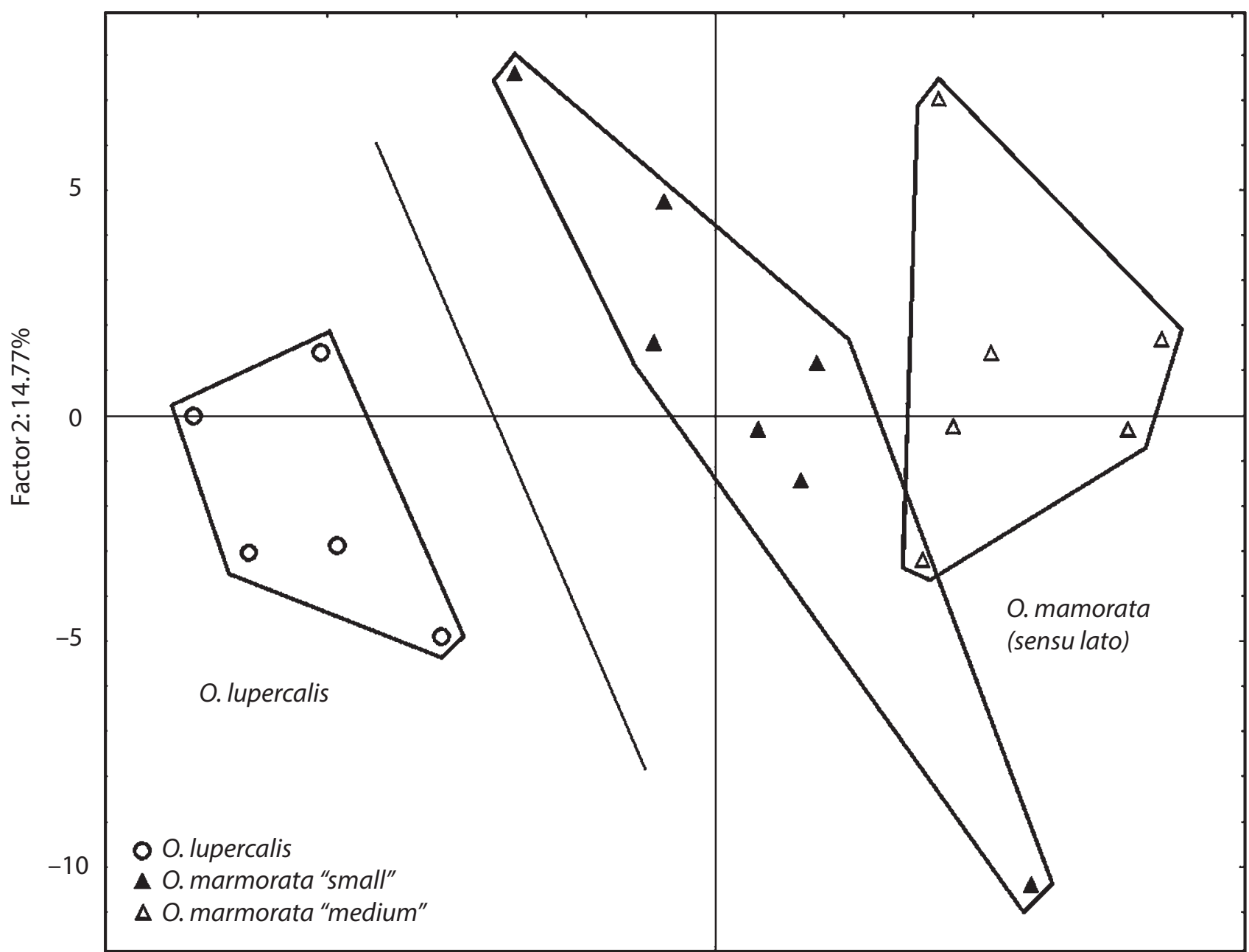

Factor 1: 19.09\%

Fig. 2 Principal component analysis summarizing variation in floral chemical signature based on 120 cuticular lipidic compounds detected using gas chromatography of labella collected from 18 samples of Ophrys lupercalis, O. marmorata 'medium-sized labellum' and O. marmorata'small labellum' collected in continental South-eastern France (Bouches-du-Rhône). Modified from Véla et al. (2007).

From now on, it will be possible to revise Ophrys taxonomy for the whole Euro-Mediterranean area on a sound and scientific basis, including at least morphology, phenology and biogeography. At each stage in the geographic expansion of the analysis, morphospecies and subspecies are distinguished respectively by diagnostic and discriminating criteria, which implies a continual revision of the general taxonomic scheme and identification keys for this genus.

\section{Acknowledgments}

This point of view was presented at the TORC' 15 international conference at Samos, Greece, 13-19 April 2015. Nina Joffard and Bertrand Schatz (UMR CEFE, CNRS / University of Montpellier, France) participated in our thinking and helped to ameliorate our manuscript.

\section{REFERENCES}

Barriau A, Chauvet M, de Prémorel G, Véla E (2011) Caractérisation morphométrique des taxons d'Ophrys section Pseudophrys (Orchidaceae) dans la région de Montpellier (SE-France). Mémoire de Licence 3 "Biologie des Organismes", Université Montpellier-2, Montpellier.

Bateman RM, Devey DS, Malmgren S, Bradshaw E, Rudall PJ (2010) Conflicting species concepts underlie perennial taxonomic controversies in Ophrys. Cah Soc Franç Orchid 7: 87-101.

Bateman RM, Bradshaw E, Devey DS, Glover BJ, Malmgren S, Sramkó G, Thomas MM, Rudall PJ (2011) Species arguments: clarifying concepts of species delimitation in the pseudo-copulatory orchid genus Ophrys. Bot J Linn Soc 165: 336-347.

Baumann H, Künkele S, Lorenz R (2006) Orchideen Europas: mit angrenzenden gebieten. Stuttgart: Ulmer.

Bournérias M, Prat D (2005) Les Orchidées de France, Belgique et Luxembourg, 2e édition. Biotope coll. Parthénope, Paris.

Breitkopf H, Onstein RE, Cafasso D, Schlüter PM, Cozzolino 
S (2015) Multiple shifts to different pollinators fuelled rapid diversification in sexually deceptive Ophrys orchids. New Phytol 207: 377-389.

Delforge P (2005) Guide des orchidées d'Europe, d'Afrique-duNord et du Proche-Orient: 3e édition. Delachaux and Niestlé, Paris.

Delforge P (2012) Guide des orchidées de France, de Suisse et du Benelux: nouvelle édition revue et augmentée. Delachaux and Niestlé, Paris.

Devey DS, Bateman RM, Fay MF, Hawkins JA (2008) Friends or relatives? Phylogenetics and species delimitation in the controversial European orchid genus Ophrys. Ann Bot 101: 385-402.

Dusak F, Lebas P, Pernot P (2009) Guide des orchidées de France. Belin, Paris.

Faurholdt N, Pedersen HÆ (2009) Flueblomster fra Marokko til Mellemøsten, Orkidéslaegten Ophrys i Nordafrika og Levanten. Dansk Orchide Klub og forfatterne, Kobenhavn.

Fournier P (1947) Les Quatre flores de la France, Corse comprise (générale, Alpine, Méditerranéenne, littorale): Nouveau tirage. Paul Lechevalier, Paris.

García-Barriuso M, Bernardos S, Amich F (2010) Chromosomal evolution in Mediterranean species of Ophrys sect. Pseudophrys (Orchidaceae): An analysis of karyotypes and polyploidy. Taxon 59: 525-537.

Joffard N, Dormont L, Schatz B (2014) Dynamique écologique et évolutive des espèces d'orchidées du genre Ophrys: du réseau d'interactions Ophrys-pollinisateurs à la délimitation des espèces de Pseudophrys français. Mémoire de Master 2 "Environnement et Gestion de la Biodiversité", Université Montpellier-2, Montpellier.

Krak K, Caklová P, Chrtek J, Fehrer J (2013) Reconstruction of phylogenetic relationships in a highly reticulate group with deep coalescence and recent speciation (Hieracium, Asteraceae). Heredity 110: 138-151.

Maire R (1960 ‘ 1959') Flore de l’Afrique du Nord (Maroc, Algérie, Tunisie, Tripolitaine, Cyrénaïque et Sahara), volume VI. Paul Lechevalier, Paris.

Martin R, Véla E, Ouni R (2015) Orchidées de Tunisie. Bull Soc Bot Centre-Ouest $n^{\circ}$ spec 44: 1-160.

Paulus HF (2006) Deceived males: pollination biology of the Mediterranean orchid genus Ophrys (Orchidaceae). J Europ Orchid 38: 303-353.

Paulus HF, Gack C (1983) Untersuchungen des Ophrys fusca - Formenkreises in Südspanien. Ein Beitrag zum Biospezieskonzept der Gattung Ophrys. Die Orchidee 34: 65-72.

Paulus HF, Gack C (1990) Pollinators as prepollinating isolation factors: evolution and speciation in Ophrys (Orchidaceae). Isr J Bot 39: 43-97.

Pedersen HÆ, Faurholdt N (2007) Ophrys, the bee orchids of Europe. Kew Publishing, Kew.
Pires AC, Marinoni L (2010) DNA barcoding and traditional taxonomy unified through Integrative Taxonomy: a view that challenges the debate questioning both methodologies. Biota Neotrop 10: 339-346.

Rebbas K, Véla E (2013) Observations nouvelles sur les Pseudophrys du centre-est de l'Algérie septentrionale. J Europ Orchid 45: 217-233.

Ritz CM, Schmuths H, Wissemann V (2005) Evolution by reticulation: European dogroses originated by multiple hybridization across the genus Rosa. J Heredity 96: 4-14.

Schlüter PM, Kohl G, Stuessy TF, Paulus HF (2007a) A screen of low-copy nuclear genes reveals the LFY gene as phylogenetically informative in closely related species of orchids (Ophrys). Taxon 56: 493-504.

Schlüter PM, Ruas PM, Kohl G, Ruas CF, Stuessy TF, Paulus HF (2007b) Reproductive isolation in the Aegean Ophrys omegaifera complex (Orchidaceae). Plant Syst Evol 267: 105-119.

Schlüter PM, Ruas PM, Kohl G, Ruas CF, Stuessy TF, Paulus HF (2009) Genetic patterns and pollination in Ophrys iricolor and O. mesaritica (Orchidaceae): sympatric evolution by pollinator shift. Botanical J Linn Soc 159: 583-598.

Schlüter PM, Ruas PM, Kohl G, Ruas CF, Stuessy TF, Paulus HF (2011) Evidence for progenitor-derivative speciation in sexually deceptive orchids. Ann Bot 108: 895-906.

Soliva M, Kocyan A, Widmer A (2001) Molecular phylogenetics of the sexually deceptive orchid genus Ophrys (Orchidaceae) based on nuclear and chloroplast DNA sequences. Mol Phylogen Evol 20: 78-88.

Souche R (2004) Les orchidées sauvages de France, grandeur nature. Les Créations du Pelican, Paris.

Tison J-M, de Foucault B (2014) Flora Gallica: Flore de France. Biotope éditions, Mèze.

Tison J-M, Jauzein P, Michaud H (2014) Flore de France méditerranéenne continentale. Naturalia publications, Turriers.

Véla E (2007) Révision taxonomique de l'Ophrys de Marseille, Ophrys aranifera Hudson subsp. massiliensis (J. Viglione and E. Véla) comb. nov., un essai de systématique intégrative. Candollea 62: 109-122.

Véla E (2008a) Les ophrys araignées et la taxonomie intégratrice. L'Orchidophile $176: 25-41$.

Véla E (2008b) Analyse d'ouvrage: Ophrys, the bee orchids of Europe. Acta Bot Gall 155: 585-588.

Vereecken NJ, Streinzer M, Ayasse M, Spaethe J, Paulus HF, Stökl J, Cortis P, Schiestl FP (2011) Integrating past and present studies on Ophrys pollination - a comment on Bradshaw et al. Botanical J Linn Soc 165: 329-335.

Xu S, Schlüter PM, Scopece G, Breitkopf H, Gross K, Cozzolino S, Schiestl FP (2011) Floral isolation is the main reproductive barrier among closely related sexually deceptive orchids. Evolution 65: $2606-2620$ 